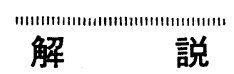

\title{
カルボキシルエステラーゼ研究の新しいアプローチ
}

\author{
塩 月 孝 博
}

農林水産省虫糸・昆虫農業技術研究所

(平成 7 年 2 月 20 日受理)

\section{New Approaches for Studies on Carboxylesterases}

\author{
Takahiro SHIotsuki \\ Department of Insect Behavior and Physiology, National Institute of Sericultural and \\ Entomological Science, Owashi, Tsukuba 305, Japan
}

\section{は じめに}

昆虫の脱皮・変態は低分子ホルモンである幼若ホルモ ンとエクダイソンの濃度バランスによって起こり, それ ら低分子ホルモンはさらにペプチドホルモン制御下にあ る. 幼若ホルモンはセスキテルペノイドのエポキシメチ ルエステルで, エステラーゼとエポキシドヒドロラーゼ によって分解される(図 1) ${ }^{1)}$. この幼若ホルモンエステ ラーゼ（JHE） は昆虫の脱皮後にその高い酵素活性が 現れ，役目の終わった幼若ホルモンを速やかに分解する もので基質特異性が非常に高いことが知られている. カ リフォルニア大学ディヴィス校昆虫学および環境毒理学 科の B.D. Hammock 教授らのグループでは, JHE を中心としたカルボキシルエステラーゼの研究を有機化 学, 生化学, 分子生物学といったさまざまな角度から行 なっている. まず, 彼らはタバコガの一種 Heliothis virescens 由来の JHEをコードする $\mathrm{cDNA}$ の配列を 決定し2)，さらにこれをプラスミドに組み込み，昆虫ウ イルスであるバキュロウイルスの発現系を利用すること で, 昆虫細胞培養液中に大量の JHE タンパクの生産を 可能とした ${ }^{3)}$. 加えて, 酵素活性の比較的安定なこの JHEを多種多様なカルボキシルエステラーゼのモデル 酵素とし, 酵素触媒反応機構やタンパク質間相互作用に 関する研究も行なっている. 筆者は, この研究室にポス ドクとして 2 年間滞在したので, そのユニークな研究手 法と取組み方について紹介したい.

\section{阻害剤の検索と基質の開発}

はじめに，この JHE の特異的阻害剂の合成的検索が 行なわれた. エステラーゼによるエステルの加水分解で は, カルボニル炭素が四面体構造の遷移状態を経ること が知られている. トリフルオロメチルケトンのカルボニ ル構造はトリフルオロメチル基による電子吸引的性質に より，結晶状態でも四面体構造をとることがわかってお り4，醅素と結合した場合にも同様の構造が示唆されて いる(図 2).したがって，トリフルオロメチルケトン構 造はメチルエステル分解の遷移状態アナログとなる可能 性が考党られ，関連化合物が設計・合成された．最初 に，幼若ホルモンと同程度の炭素鎖をもつ 1, 1, 1-trifluoromethyl-2-tetradecanone (TFT, 図 3) に JHE 阻害活性が認められた ${ }^{5}$. 構造と醉素阻害活性との関係 を調べると，幼若ホルモンに存在するような側鎖や二重 結合はとくに必要ではなく，アルキルチオ基をもつトリ フルオロメチルアセトンに高い活性が見いだされた.さ らに，そのアルキル鎖の長さに最適值が存在することが わかり，3-(n-octylthio)-1,1,1-trifluoro-2-propanone (OTFP) がもっとも高い阻害活性を示した6). 阻害形式 は, 本来の基質, 幼若ホルモンと拮抗するが, 酥素のこ の阻害剂に対する親和性がきわめて高いためにその阻害 は見かけ上不可逆的であった。

JHE 酵素活性は，トリチウムでラベルされた幼若ホ ルモンを基質とし, 酵素反応停止後, イソオクタンで未 反応基質を抽出することによって，水層に残ったエステ ル加水分解物の放射活性を液体シンチレーションカウン 
<smiles>[R]C(=CC(=O)OC)CCCC(P)=CCCC1OC1([R])C</smiles>

\section{JH (active)}

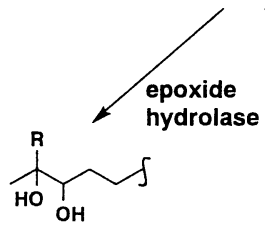

JH diol (inactive)

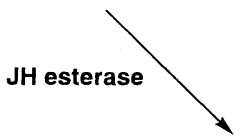

JH acid (inactive)

JH diol acid (inactive)

図 1 幼若ホルモン $(\mathrm{JH})$ の酵素による分解経路

ターで測定する方法で行なわれてきた7). しかし，この 操作は煩雑で昆虫血液中の JHE 活性の経時変化を調べ たり，酵素タンパクの精製の際のように，速やかに多くの 試料の活性測定を行なわなければならない場合には適さ ない．そこで簡便な活性測定法の開発を行なった．幼若 ホルモンのメチルエステルをメチルチオエステル構造に することにより,本来の構造をできるだけ保持したまま， 加水分解で遊離する $\mathrm{CH}_{3} \mathrm{~S}^{-}$の Ellman 法による比色定 量を可能とした．前述のトリフルオロメチルケトンの構 造と阻害活性の相関研究から，直鎖カルボン酸や構造の 一部にへテロ原子をもつカルボン酸のメチルチオエステ ルを設計・合成した $\left(\right.$ 図 4) ${ }^{8}$ ．幼若ホルモンとほぼ同様 の長さの直鎖カルボン酸メチルチオエステル等が, JHE
により分解された．さらに阻害剤検索のとさと同様に， カルボニルの $\beta$ 位にアルキルチオ基をるつ酢酸メチルチ オエステルが良い成績を示し, 非䤃素的分解が小さく, 醉素の基質に対する親和性も高かった．それらのなかで methyl $n$-heptylthioacetothioate (MHTAT) が速度 論的にもっとも優れた基質の性質を示した．また，この 酵素反応を, $0.3 \mathrm{ml}$ にスケールダウンすることで， マ イクロタイタープレート上で多試料（96 サンプル，実 際には 3 連あるいは 4 連で行なうので 32 あるいは $24+$ ンプル）を数分内に測定することが可能となった。この 新規基質を用いてタバコスズメガ終秢幼虫の血液に存在 する JHE 活性を経時的に測定すると，トリチウムラべ ル幼若ホルモン III を基質として用いた場合の結果に よく一致した ${ }^{9)}$.

$$
\text { アフィニティークロマトグラフィーによる精製 }
$$

次に，醭素の親和性がきわめて高かった OTFP の類 似構造をリガンドにもつアフィニティークロマトグラフ ィーによる JHE の精製を行なった。 セファロース樹脂 の水酸基を, ジグリシジルエーテルでエポキシ活性化し た後, 3- (4-mercaptobutyl)-1, 1, 1-trifluoro-2-propanone (MBTFP, 図 5) の SH 基と反応させたアフィ ニティーゲルををず得た。この系は JHE に対する特 異性が高く，昆虫血液中からの精製において有効であっ た ${ }^{10)}$. しかし，この場合，䤃素に対する親和性がきわめ て高いため溶出されにくく，もっとも阻害活性の高い OTFPによってからうじて溶出されるものであった. しかし, 得られた酵素-阻害剤複合体の酵素活性回復が 容易でなかったため，酥素に対する親和性を制御したり

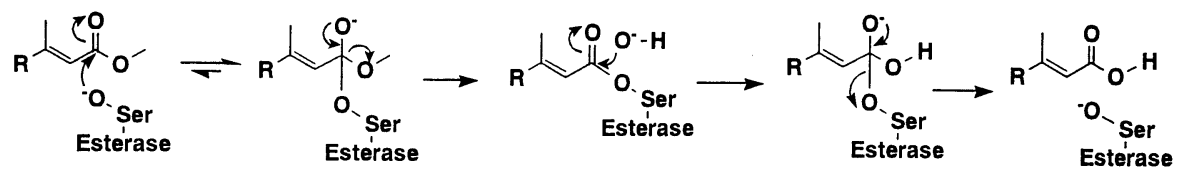

(a) Esteratic hydrolysis of $\mathrm{JH}$

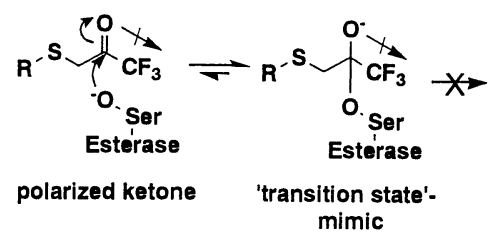

(b) Inhibition of JH Esterase

図 2 (a) JH エステラーゼによる JH 加水分解反応機構と，(b) トリフルオロメチルケトンによ る $\mathrm{JH}$ エステラーゼの阻害 
<smiles>COC(=O)/C=C(\C)CC/C=C(\C)CCC1OC1(C)C</smiles>

JH III
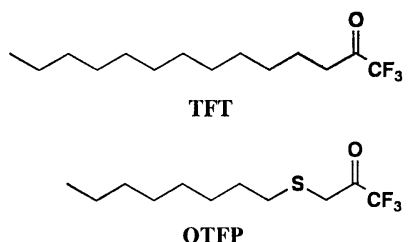

図 3 JH III とトリフルオロメチルケトン阻害剂 の構造
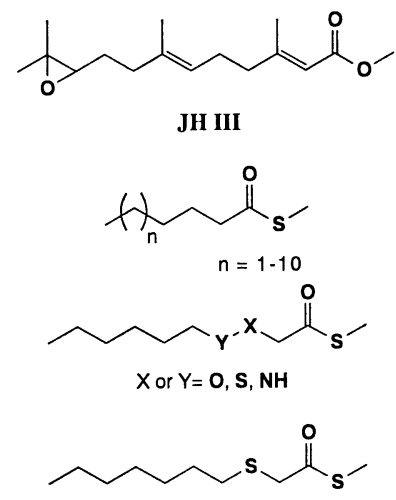

MHTAT

図 4 JH III とメチルチオエステル骨格をもつ新 規合成基質の構造<smiles>[R]CC(O)COCCCCOCC(O)CO[14CH2][13CH2][13CH3]</smiles>

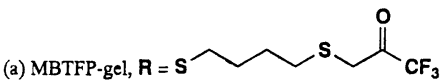<smiles>O=C(CCCCCCS[SH]=POC=[18O])C(F)(F)F</smiles>

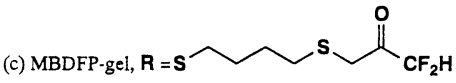
(d) MPTFP-gel, $\mathbf{R}=\mathbf{S}$<smiles>Cc1cccc(SCC(=O)C(F)(F)F)c1</smiles>

図 5 アフィニティーリガンドとゲルの構造
ガンドの設計を行なったと方法として分子全体の長 さは変えず, MBTFPからフッ素が一つ少ないもの (MBFP), B構造の一部に芳香環をもつもの (MPTFP), スルフィドをメチレンに変換したもの（8-mercapto-1, 1,1-trifluoro-2-octanone, MTFO）を合成し，アフィ ニティーゲルをそれぞれ調製した。 そのなかで，フッ素 が少ない MBDFP ゲルは予想に反して MBTFP ゲル と同様に酵素に対する高い親和性を示し，芳香環をもつ MPTFP ゲルは逆に酵素を吸着しなかった。 それらの 中間の性質を示したのが,スルフィドをもたないMTFO ゲルであった。このゲルを用いて溶出条件を検討した結 果, 非イオン系界面活性剤オクチルグルコシド存在下, OTFP より炭素鎖の短い，すなわち，阻害活性が低い トリフルオロメチルケトンでの溶出が可能となり，続く 透析によって界面活性剤と阻害剤を同時に除去すること ができ，酵素活性の回復した精製酵素が得られた ${ }^{11)}$ 。得 られた酵素の精製比および精製度はいずれも DEAEイオン交換クロマトグラフィーで精製したものよりも高 かった．この精製方法により，クローニングされた酵素 を大量に発現した昆虫細胞培養液から，ミリグラム単位 の活性をもつ精製酵素を得ることに成功した。

\section{活性中心と糖鎖結合部位の検索}

トリプシン等のセリンプロテアーゼは, Ser-His-Asp の触媒官能基系を活性中心にもつことが知られている. エステラーゼでもその活性中心にセリンを含む同様の触 媒官能基系の存在が考えられていたが，明確には証明さ れていなかった．そこでクローニングされた酵素の活性 中心を遺伝子側から検索した. H. virescens の JHE の アミノ酸配列を，セリンを活性中心にもつエステラーゼ やリパーゼなどと比較すると, Ser (201), His (446), Glu (332), Asp (173), Arg (57) などの前後に類似の 共通配列が認められた。これらの各残基を性質の異なる 残基へ塩基置換により部位特異的変異を行ない変異型遗 伝子を得, 前述のバキュロウイルスを用いた発現系によ り JHEミュータントを得た。醭素活性を比較すると， $\operatorname{Ser}(201) \rightarrow \operatorname{Gly}(201$ 番目のセリンをグリシンに変換し たミュータントのことを示す), His (446) $\rightarrow$ Arg, Glu (332) $\rightarrow$ Gln, Asp (173) $\rightarrow$ Asn の各ミュータントの活

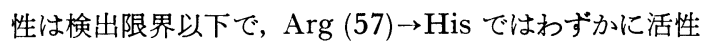
が認められた ${ }^{12)}$.これらの残基は, いずれも触媒反応や夕 ンパクの高次構造形成に関与しているものと考えられ， 最近の他の研究をあわせ考えると JHE の Ser (201)His (446)-Glu (332) がセリンプロテアーゼの SerHis-Asp に相当するものと推測された（図 6). 次に， 


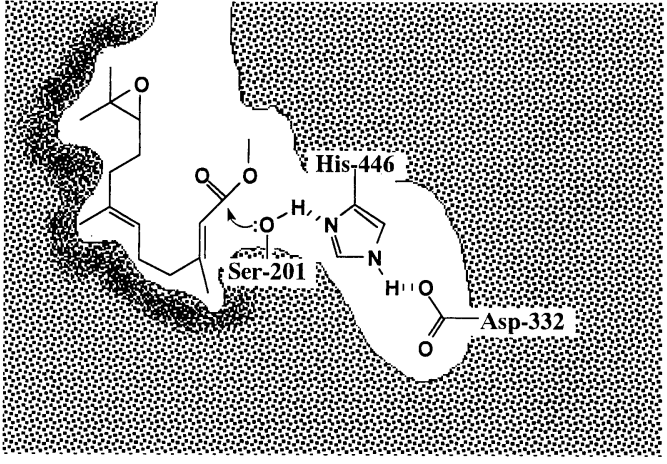

図 $6 H$. virescens の JH エステラーゼの活性中心 にあると想定される触媒官能基系

この活性中心の重要残基に関しては，化学修飾による検 索も試みた．セリン残基のほかに，トリプトファン，ヒ スチジン残基を選択的に修飾する化合物群が JHE 活性 を強く阻害した、デンキウナギのアセチルコリンエステ ラーゼの結晶構造解析から，活性中心近傍に存在するト リプトファン残基は，基質結合に関与しているものと考 兄られており，JHEでも同様の可能性が示唆された。 また，ヒスチジン残基修飾剤による阻害は，活性中心で 酵素触媒反応に同残基が係わっていることを支持するも のである.

この JHE は糖鎖をもっており，分子の親水性が高い ため結晶性が悪い性質をもつこれは，たとえば，X 線 解析を行なう場合の障害となるので，糖鎖を切断するか 糖鎖をもたないような調製法が求められる。一方，JHE は室温でも長期間安定で, 凍結一解凍の繰り返しにも酵 素活性低下の程度が小さいので, 前述のメチルチオエス テルを基質とした比色定量法を用いることにより，ウシ 粘膜アルカリフォスファターゼや西洋ワサビペルオキシ ダーゼのように，抗体標識酵素として利用できる可能性 が高い，この場合，耐溶媒性が高いものほど良いが，こ の場合も糖鎖がないほうが好ましい。一般に Asn-XaaSer/Thr 配列をもつアスパラギンが窒素を介して糖鎖 と結合することが知られている，そこで，JHEの分子 中にこの配列をもつ四つのすべてのアスパラギンを部位 特異的塩基置換法によりグルタミン，あるいは，リシン に変換したミュータントを設計し発現させた ${ }^{13)}$. 発現速 度は小さかったが，糖鎖に親和性をもつタンパク，コン カナバリン $\mathrm{A}$ に吸着せず，得られたミュータントに糖 鎖がないことを確認した。酵素活性に与える $\mathrm{pH}$ の影 響を調べると，このミュータントでもとくに安定性は低 下していなかった．続いて耐溶媒性を評価する目的で，
異なるエタノール濃度条件下で酵素活性を調べた. 元の 糖鎖をもつ酵素では，エタノール濃度が $10 \%$ を超える と酵素活性が著しく低下したのに対し，糖鎖をもたない ミュータントでは逆に大きく活性が増大し，17\% の高 濃度でもコントロールと同程度の活性を示した。

\section{哺乳動物のカルボキシルエステラーゼ}

昆虫 JHE を対象とした研究手法は, 哺乳動物のカル ボキシルエステラーゼ研究にも応用可能と考えられた. それはトリフルオロメチルケトン阻害剤が哺乳動物のエ ステラーゼ類の多くを阻害するからである ${ }^{14)}$.カルボキ シルエステラーゼ活性測定は, $p$-ニトロフェニルアセ テートや1-ナフチルアセテートを基質とするのが一般 的である、これらは大きなアルコールと小さな酸のエス テルであるので，小さなアルコールと大きな酸の組合せ である JHE 基質として開発された前述のメチルチオエ ステル類のマウス肝カルボキシルエステラーゼによる分 解を調べた ${ }^{15)}$. 酸部分の構造の違いによる基質選択性が JHE の場合と異なるのは当然であるが，そのうちいく つかはр-ニトロフェニルアセテートや 1-ナフチルアセ テートよりも非酵素的分解が小さく，かつ，酵素に対す る親和性が高いなど速度論的に優れた性質を示した。こ れらは，広くカルボキシルエステラーゼ研究に有用な基 質となるであろう。

昆虫 JHE のアイソザイムは少なく，たとえば前述の $H$. virescens では単一であるのに対し, 哺乳動物の肝力 ルボキシルエステラーゼは 15 以上ものアイソザイムが 存在する，個々の役割の解明を含め，生化学的，分子生 物学的研究にはまず各アイソザイムの分離・精製が必要 であり，現在，主要なアイソザイムはゲルろ過やイオン 交換クロマトグラフィーによって行なわれている(15)。そ こで，JHE 精製に用いたアフィニティークロマトグラ フィーのマウス肝カルボキシルエステラーゼ精製への応 用を試みた。 まず，溶出に用いる化合物，トリフルオロ メチルケトンの阻害活性と阻害された䣼素の透析による 活性回復を調べた結果，JHE と同様に炭素鎖の長さと 阻害活性に比例関係が認められた。調製したアフィニ ティーゲルの一つを用いると一部のタンパクが結合し， 特異的阻害剂で溶出された。しかし，JHEに比べ精製 後の酵素の安定性が小さかったため, 得られた画分に活 性回復が認められなかった ${ }^{17)}$. 精製後の酵素タンパクの 安定化が確立されれば，数種の異なったりガンドをもつ アフィニティークロマトグラフィーの使い分けによりア イソザイムの分離・精製が 可能となるであろう。さら にこのアフィニティークロマトグラフィーを用いた精 
製法を遅延性神経毒性に関与する脳のエステラーゼ精製 への応用を試みた例もある ${ }^{18,19)}$.

\section{おわりに}

以上，JHEを中心とした最近のカルボキシルエステ ラーゼ研究例を紹介した. 近年めざましい分子生物学の 研究手法を取り入れ, 同時に生物有機化学の観点から取 り組むことでエステラーゼのタンパク質化学においては 新しい展開がもたらされた。しかし，さまざまなカルボ キシルエステラーゼの生理的な意義については JHE 以 外ではそれほどょくわかっておらず，今後明らかにされ なければならない，とくに哺乳動物に数多く存在するア イソザイムの役割を各々について明らかにすることは， 医薬や農薬開発においても重要な知見を与兄るものであ る.ささに，生物種間やアイソザイム間での基質特異 性, あるいは, アミノ酸（とそれをコードする塩基）配 列などの比較研究は, カルボキシルエステラーゼの分子 進化のメカニズム解明等に大きく寄与するものと考光ら れる。

\section{引 用 文 献}

1) B.D. Hammock: "Comprehensive Insect Physiolgy, Biochemistry, and Pharmacology," ed. by G.A. Kerkut \& L.I. Gilbert, Vol. 7, Pergamon Press, New York, pp. 431-472, 1985

2) T.N. Hanzlik, Y.A.I. Abdel-Aal, L.G. Harshman \& B.D. Hammock: J. Biol. Chem. 264, 12419 (1989)

3) B.D. Hammock, B.C. Bonning, R.D. Possee, T.N. Hanzlik \& S. Maeda: Nature 344, 458 (1990)

4) M.M. Olmstead, W.K. Musker \& B.D. Hammock: Acta Crystallogr. C43, 1726 (1987)

5) B.D. Hammock, K.D. Wing, J. McLaughlin,
V.M. Lovell \& T.C. Sparks: Pestic. Biochem. Physiol. 17, 76 (1982)

6) B.D. Hammock, Y.A.I. Abdel-Aal, C.A. Mullin, T.N. Hanzlik \& R.M. Roe: Pestic. Biochem. Physiol. 22, 209 (1984)

7) B.D. Hammock \& T.C. Sparks: Anal. Biochem. 82, 573 (1977)

8) B.F. McCutchen, T. Uematsu, A. Szekacs, T.L. Huang, T. Shiotsuki, A. Lucas \& B.D. Hammock: Arch. Biochem. Biophys. 307, 231 (1993)

9) B.F. McCutchen, A. Szekacs, T.L. Huang, T. Shiotsuki \& B.D. Hammock: Insect Biochem. Mol. Biol. 25, 119 (1995)

10) Y.A.I. Abdel-Aal \& B.D. Hammock: Science 233, 1073 (1986)

11) T. Shiotsuki, T.L. Huang, T. Uematsu, B.C. Bonning, V.K. Ward \& B.D. Hammock: Protein Express. Purif. 5, 296 (1994)

12) V.K. Ward, B.C. Bonning, T.L. Huang, T. Shiotsuki, V.N. Griffeth \& B.D. Hammock: Int. J. Biochem. 24, 1933 (1992)

13) V.K. Ward, P.G. Schneider, T. Shiotsuki, S.B. Kreissig, P.V. Choudary \& B.D. Hammock: Insect Biochem. Mol. Biol. (submitted)

14) M-B.A. Ashour \& B.D. Hammock: Biochem. Pharmacol. 36, 1869 (1987)

15) T.L. Huang, T. Uematsu, T. Shiotsuki, B. Borhan \& B.D. Hammock: Abstr.; 207th Am. Chem. Soc. Natl. Meet., San Diego, MEDI-269, 1994

16) M. Hosokawa, T. Maki \& T. Sato: Avch. Biochem. Biophys. 277, 219 (1990)

17) T. Shiotsuki, T.L. Huang \& B.D. Hammock: J. Pesticide Sci. 19, 321 (1994)

18) T.C. Thomas, A. Szekacs, S. Ro;as \& B.D. Hammock: Biociem. Pharmacol. 40, 2587 (1990)

19) T.C. Thomas, A. Szekacs, B.D. Hammock, B.W. Wilson \& M.G. McNamee: Chem. -Biol. Interactions 87, 347 (1993) 